Santa Clara University

Scholar Commons

Civil Engineering

School of Engineering

$1-2004$

\title{
Potential effects of long-lead hydrologic predictability on Missouri River main-stem reservoirs
}

Edwin P. Maurer

Santa Clara University, emaurer@scu.edu

Dennis P. Lettenmaier

Follow this and additional works at: https://scholarcommons.scu.edu/ceng

Part of the Civil and Environmental Engineering Commons

\section{Recommended Citation}

Maurer, E.P. and D.P. Lettenmaier, 2004, Potential effects of long-lead hydrologic predictability on Missouri River main-stem reservoirs, J. Climate 17(1) 174-186

(C) Copyright 2004 American Meteorological Society (AMS).

This Article is brought to you for free and open access by the School of Engineering at Scholar Commons. It has been accepted for inclusion in Civil Engineering by an authorized administrator of Scholar Commons. For more information, please contact rscroggin@scu.edu. 


\title{
Potential Effects of Long-Lead Hydrologic Predictability on Missouri River Main-Stem Reservoirs*
}

\author{
EDWIN P. MAURER \\ Department of Civil Engineering, Santa Clara University, Santa Clara, California \\ DenNis P. LETTENMAIER \\ Department of Civil and Environmental Engineering, University of Washington, Seattle, Washington
}

(Manuscript received 4 October 2002, in final form 18 June 2003)

\begin{abstract}
Understanding the links between remote conditions, such as tropical sea surface temperatures, and regional climate has the potential to improve streamflow predictions, with associated economic benefits for reservoir operation. Better definition of land surface moisture states (soil moisture and snow water storage) at the beginning of the forecast period provides an additional source of streamflow predictability. The value of long-lead predictive skill added by climate forecast information and land surface moisture states in the Missouri River basin is examined. Forecasted flows were generated that represent predictability achievable through knowledge of climate, snow, and soil moisture states. For the current main-stem reservoirs $\left(90 \times 10^{9} \mathrm{~m}^{3}\right.$ storage volume $)$ only a $1.8 \%$ improvement in hydropower benefits could be achieved with perfect forecasts for lead times up to one year. This low value of prediction skill is due to the system's large storage capacity relative to annual inflow. To evaluate the effects of hydrologic predictability on a smaller system, a hypothetical system was specified with a reduced storage volume of $36 \times 10^{9} \mathrm{~m}^{3}$. This smaller system showed a $7.1 \%$ difference in annual hydropower benefits for perfect forecasts, representing $\$ 25.7$ million. Using realistic streamflow predictability, \$6.8 million of the $\$ 25.7$ million are realizable. The climate indices provide the greatest portion of the $\$ 6.8$ million, and initial soil moisture information provides the largest increment above climate knowledge. The results demonstrate that use of climate forecast information along with better definition of the basin moisture states can improve runoff predictions with modest economic value that, in general, will increase as the size of the reservoir system decreases.
\end{abstract}

\section{Introduction}

Better understanding of the links between remote conditions, such as tropical sea surface temperatures, and climate over the continental United States has facilitated improved land surface hydrologic predictability, manifested especially in more accurate streamflow forecasts, especially for lead times longer than are achievable through traditional methods (Wood et al. 2002; Baldwin 2001; Hamlet and Lettenmaier 1999; Garen 1998). In addition to these climate teleconnections, better definition of the land surface moisture state at the time of the forecast, through macroscale hydrologic modeling and remote sensing provides additional opportunities for

\footnotetext{
* Joint Institute for the Study of the Atmosphere and Ocean Contribution Number 938.
}

Corresponding author address: Dennis P. Lettenmaier, Department of Civil and Environmental Engineering, University of Washington, Box 352700, Seattle, WA 98195-2700.

E-mail: lettenma@ce.washington.edu improved hydrologic forecasting (e.g., Walker and Houser 2001; Pauwels 2001; Rango et al. 2000; Carroll et al. 1999).

Remote climate forcing signals and initial land surface states have been shown to provide a measure of predictability of runoff over the Mississippi River basin (Maurer and Lettenmaier 2003), with considerable spatial variability in the degree of predictability, its sources, and the lead times at which it is significant. Studies of the predictability of streamflow and/or of related climatic forcing variables, and implied benefits to water resources systems are numerous (e.g., Goddard et al. 2001; Hu and Feng 2001; Fennessy and Shukla 2000; Cayan et al. 1999; Dracup and Kahya 1994; Kahya and Dracup 1993). However, studies that have made quantitative evaluations of the economic value of land surface hydrologic predictability are more rare (e.g., Hamlet et al. 2002; Yao and Georgakakos 2001; Yeh et al. 1982; Castruccio et al. 1980).

The National Research Council (2002a) identified the key to operational implementation of research findings related to hydrologic predictability as communication 


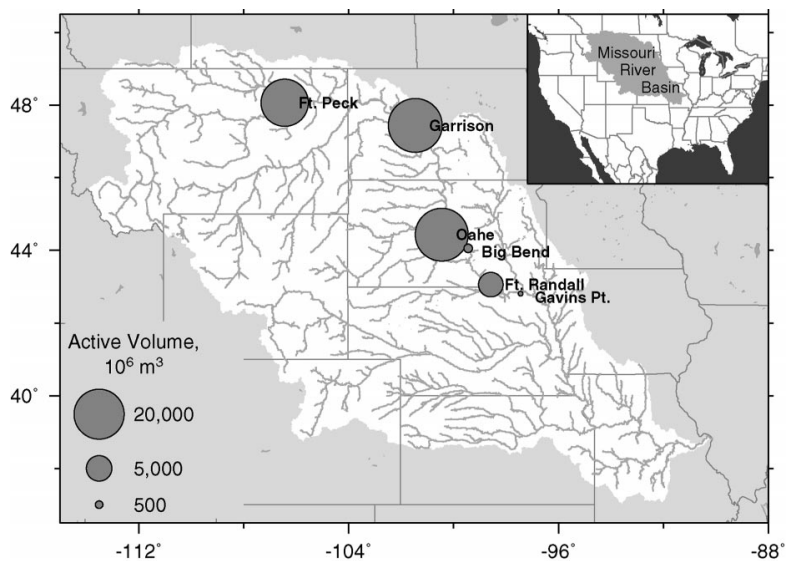

FIG. 1. Missouri River main-stem dams. Size of circle at each point is scaled according to the ratio of the active storage volume to the river flow at that point.

and strong linkages between research institutions and operational programs. However, an essential component of operational implementation of new techniques or data products (such as satellite-derived land surface characterizations) to improve predictability is a demonstration of the benefits that the improved predictability may bring. Hornberger et al. (2001) assert that "improved information systems and prediction methods can lead to large benefits for water, land, and biological resource management ..." In this study we build on previous work by Maurer and Lettenmaier (2003) that identified levels of predictability due to climate and land surface sources throughout the Mississippi River basin, and investigate how large an effect long-lead predictability can have on a water resource system, in comparison to that predictability already available.

Specifically, this study evaluates the impact of streamflow predictability at long lead times (months to a year) on reservoir operation in the main-stem Missouri River system, which includes six dams managed by the U.S. Army Corps of Engineers (COE; Fig. 1). The Missouri River basin was selected due to the demonstrable long-lead runoff predictability in the basin (Maurer and Lettenmaier 2003) and the extensive network of water management facilities that allow water managers to respond to monthly and seasonal forecast knowledge. We develop a simplified simulation model of the system of reservoirs, and use this reservoir simulation model to evaluate the bounding cases of perfect predictability and no prediction skill. We then use estimates of realistically achievable streamflow predictability determined by Maurer and Lettenmaier (2003) to compute the value of predictive skill associated with knowledge of remote climate forcing impacts of Missouri River streamflow, as well as knowledge of initial snow water content and soil moisture over the basin.
TABLE 1. Ratio of the total volume and active volume for each dam (the reservoir volume minus the permanent pool storage) to the average annual flow at each site.

\begin{tabular}{lcc}
\hline \hline \multicolumn{1}{c}{ Dam } & $\begin{array}{c}\text { Total vol/ } \\
\text { avg annual flow }\end{array}$ & $\begin{array}{c}\text { Active vol/ } \\
\text { avg annual flow }\end{array}$ \\
\hline Fort Peck & 3.0 & 1.8 \\
Garrison & 1.6 & 1.0 \\
Oahe & 1.4 & 0.8 \\
Big Bend & 0.1 & 0.02 \\
Fort Randall & 0.4 & 0.2 \\
Gavins Point & 0.03 & 0.01 \\
\hline
\end{tabular}

\section{Study site description}

The Missouri River is one of the largest rivers in North America, and in its virgin state exhibited highly variable flows. A combination of the Great Depression and the Dust Bowl of the early 1930s inspired the construction of Fort Peck dam, one of the largest modern structures on the planet (Reisner and Bates 1990), which was completed on the upper main stem of the Missouri River in 1940. A sequence of three large floods in 1943 compelled the COE to draft plans for five additional large main stem dams, the last of which was completed in 1964 (Reisner 1986). The motivation for drought and flood protection resulted in the enormous system design volume, which is intended to provide protection against both a repeat of the 12-yr 1930s drought (Lund and Ferreira 1996) and the 1881 flood of record (COE 1999). The system is currently operated to provide hydropower, flood control, navigation, water supply, recreation, and environmental mitigation benefits, although evacuating storage for spring runoff and releasing sufficient flow for downstream navigation largely drive the annual system operation. For example, the total annual requirements for irrigation, municipal, industrial, livestock, and all water uses in tributary areas to the main-stem dams averages less than $200 \mathrm{~m}^{3} \mathrm{~s}^{-1}$ (COE 1998), or about one-third of the required release for navigation, even in drought years.

The Missouri River basin and the six main stem dams are shown in Fig. 1. The three upstream main-stem reservoirs are significantly larger than the three downstream reservoirs. Table 1 shows the relative abilities of these reservoirs to regulate flow, expressed as the total active reservoir storage volume (excluding the permanent pool storage) divided by the average annual main-stem flow at the dam site. The most upstream dam, Fort Peck, has the largest ratio, with an active storage capacity of 1.8 times the average annual inflow. The overall dominance of the upper three dams for water management purposes at time scales greater than one month is clearly shown. Of the total annual flow at Gavins Point $\left(23.3 \times 10^{9} \mathrm{~m}^{3}\right), 89 \%$ is generated upstream of Oahe Dam, which highlights the importance of the upstream three reservoirs in regulating the annual flow variations. The downstream reservoirs provide additional hydropower generation and flow regulation over 

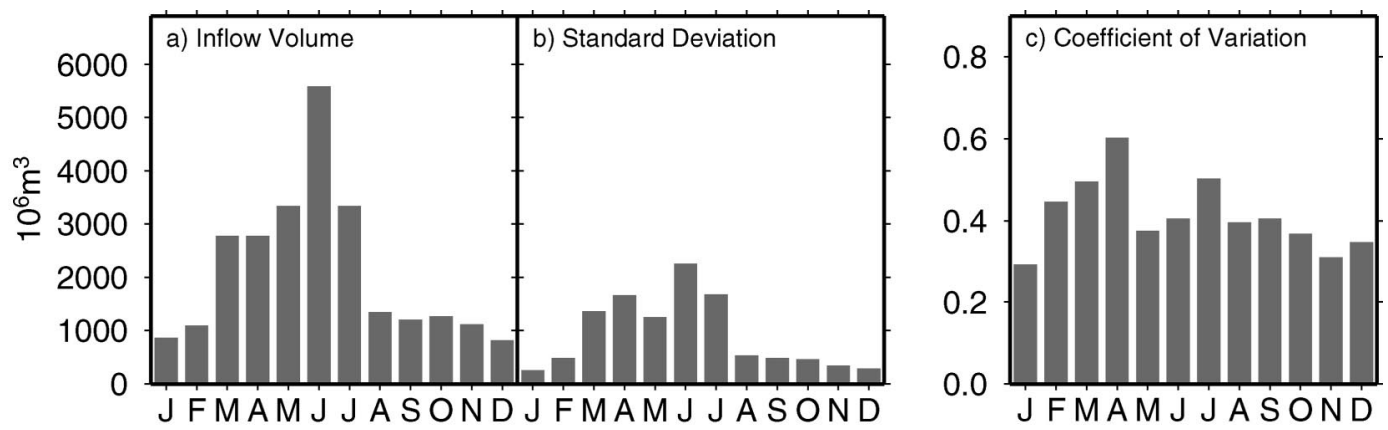

FIG. 2. (a) Monthly mean inflow to upper three reservoirs in the Missouri River main-stem system; (b) std dev of the monthly inflows; (c) coefficient of variation.

shorter time spans. With these large storage capacities, the Missouri River main-stem system is capable of responding to long-lead forecasts by adapting water storage and release decisions to anticipated inflows months to a year in advance.

Figure $2 \mathrm{a}$ shows the average annual cycle of inflow to the upper three reservoirs, which is dominated by snowmelt in the spring and early summer. The standard deviation of the flows is shown in Fig. 2b, which indicates that the variability is greatest in the spring and early summer. Figure $2 \mathrm{c}$ shows the coefficient of variation (standard deviation divided by the mean), and illustrates that, relative to the mean inflow, the greatest variability in streamflow occurs in spring, meaning that predictability of spring and early summer flows can be expected to have the greatest impact on system operation.

\section{Methods}

The potential seasonal predictability of runoff identified by Maurer and Lettenmaier (2003) for the Mississippi River basin implied an inherent benefit to water resources management. In order to quantify this benefit for the Missouri River main-stem reservoir system, and to reveal the impact of increased predictability at long lead times on water resources management, a simulation model of the system of reservoirs was developed. The methods used in developing and applying the model are explained below.

\section{a. Predictability for contributing areas}

Maurer and Lettenmaier (2003) computed for each season the $r^{2}$, representing predictability, associated with a multiple linear regression between selected initial conditions (i.e., different combinations of knowledge of climate or land surface conditions) and the seasonal average runoff at each of $15320.5^{\circ}$ grid cells in the Mississippi River basin. The 51-yr (1950-2000) time series of derived seasonal soil moisture, snow, and climate indices were regressed against the corresponding seasonal average runoff data for the specified lead time at each grid cell. All data were used in the developing the regression relationships; for example, all $51 \mathrm{yr}$ of spring runoff values at a single grid cell were correlated with the values of the climate indices, soil moisture, and snow at that grid cell at the specified lead time. The $r^{2}$ values were computed for seasons at leads of $0-4$ seasons (where lead 0 would be a forecast of a season's runoff using initial conditions of the first day of the season, or an average of 1.5-month lead time). These $r^{2}$ values were computed independently for each grid cell. Streamflow forecasts were not produced per se, rather the spatially distributed characteristics of runoff predictability and its sources were assessed. The $r^{2}$ associated with any correlation is numerically equal to the coefficient of prediction, $C_{p}$, defined in the appendix, and we use these terms interchangeably throughout.

The climatic indicators used by Maurer and Lettenmaier (2003) are the Southern Oscillation index (SOI), which is an indicator of the state of the El Niño-Southern Oscillation, in combination with an Arctic Oscillation (AO) index. Both of these climate indices are published in near-real time, and hence are currently available to water managers. Although the evolution of these indices through the forecast period is not considered, Maurer and Lettenmaier (2003) show that the predictability of runoff achieved using their states at the time of forecast are comparable to what is obtained by considering the evolution of climate state indicators in the Missouri and Mississippi River basins.

Seasonal average soil moisture and snow (as snow water equivalent) data at each grid cell were derived using a hydrologic model driven by gridded observed, and derived from observed, meteorology as summarized by Maurer et al. (2002), and hence represent a "perfect" knowledge of the soil moisture and snow state at the time the forecast is made (because this same hydrological model simulation produced the runoff value at each grid cell for the forecasted month).

For the present study, these $C_{p}$ values (e.g., Fig. 6 in Maurer and Lettenmaier 2003) are averaged over each of the contributing areas for the upstream three Missouri River reservoirs, weighting by the average runoff for each grid (Fig. 5 in Maurer and Lettenmaier 2003). 
TABLE 2. Seasonal weighted average $C_{p}$ values for the contributing area to Fort Peck dam, derived from Maurer and Lettenmaier (2003) for the cases of different predictors (see text). Leads indicate the number of intervening seasons between the forecast date and the forecasted seasonal average runoff. Seasons are winter (DJF), spring, (MAM), summer (JJA), and fall (SON).

\begin{tabular}{|c|c|c|c|c|c|}
\hline & Lead 0 & Lead 1 & Lead 2 & Lead 3 & Lead 4 \\
\hline \multicolumn{6}{|c|}{ Predictors: Climate indicators } \\
\hline DJF & 0.046 & 0.041 & 0.065 & 0.076 & 0.04 \\
\hline MAM & 0.039 & 0.044 & 0.038 & 0.049 & 0.04 \\
\hline JJA & 0.064 & 0.075 & 0.08 & 0.083 & 0.096 \\
\hline SON & 0.031 & 0.046 & 0.038 & 0.03 & 0.033 \\
\hline \multicolumn{6}{|c|}{ Predictors: Climate indicators + snow water content } \\
\hline DJF & 0.124 & 0.045 & 0.078 & 0.092 & 0.093 \\
\hline MAM & 0.113 & 0.116 & 0.038 & 0.062 & 0.055 \\
\hline JJA & 0.346 & 0.185 & 0.176 & 0.127 & 0.141 \\
\hline $\mathrm{SON}$ & 0.048 & 0.06 & 0.059 & 0.067 & 0.034 \\
\hline \multicolumn{6}{|c|}{ Predictors: Climate indicators + snow water content + soil moisture } \\
\hline DJF & 0.672 & 0.311 & 0.187 & 0.145 & 0.148 \\
\hline MAM & 0.276 & 0.271 & 0.099 & 0.091 & 0.089 \\
\hline JJA & 0.393 & 0.203 & 0.196 & 0.14 & 0.15 \\
\hline SON & 0.179 & 0.12 & 0.091 & 0.096 & 0.062 \\
\hline
\end{tabular}

While, as mentioned above, streamflow forecasts were not produced (at either grid cells or along rivers) by Maurer and Lettenmaier (2003), by aggregating these $C_{p}$ values spatially in this manner, the overall predictability of runoff due to the considered climatic and land surface moisture indicators for each contributing area can be assessed. These values of weighted average $C_{p}$ were developed for each season and each lead time of 0-4 seasons. A grid consisting of all values of 1 represents perfect predictability, and all 0 values indicates no predictive skill. In addition to these bounding conditions, $C_{p}$ values were estimated for three scenarios: 1) for the case of known climatic indicators; 2) for the case where perfect knowledge of snow water equivalent is added to the knowledge of climate signals; and 3) for the case where perfect soil moisture knowledge is also assumed, in addition to snow water content and climate signals. As discussed by Maurer and Lettenmaier (2003), these three scenarios are arranged as "tiers" in accordance with how well defined the variables are with current technology. The climate indices are best known, as they are available in real time. Snow state is less well known, although ground surveys and remote sensing provide a basis for estimates that are available to water managers. Soil moisture is essentially unobserved, and hence is least well known. The difference between the $C_{p}$ values for each scenario represents the incremental variance explained beyond that already achieved with better known variables, hence, the variances explained by correlated variables (such as soil moisture and snow) are only counted once, and are attributed to the better known variable.

The seasonal $C_{p}$ values for Fort Peck are shown in Table 2 for each of the three cases. The table indicates the runoff variance explained by each tier of variables, by correlating the seasonal average runoff with the initial state conditions of the indicated set of predictors for the corresponding lead time. For example, the $C_{p}$ value for predicting December-January-February (DJF; hereafter all three-month units will be abbreviated by the first letter of each month) seasonal average runoff at lead 0 indicates the predictors were specified on 30 November. The table shows the general decrease in predictability with increasing lead time, the high levels of predictability identified by Maurer and Lettenmaier (2003) for winter runoff at short lead times (attributable primarily to knowledge of soil moisture), and the important role of knowledge of snow water content for summer runoff predictability. Though not shown in the table, for the contributing areas to the Garrison and Oahe dams, snow is of less importance for summer runoff prediction, and is of greater importance for spring runoff prediction, although only at lead times less than about three months.

Maurer and Lettenmaier (2003) developed the $C_{p}$ predictability indices at the seasonal average scale, and the water resources system simulation model developed in this study for the Missouri River basin operates on a time step of one month, so as to capture the essential subseasonal operational water management decisions. The seasonal $C_{p}$ values were interpolated to monthly values for lead times of $0-11$ months, where a lead time of 0 months indicates a forecast of a month's average runoff on the first day of the month. A $12 \times 12$ grid represents these monthly $C_{p}$ values for each incremental area, with one row for each month for which flow is being predicted, and one column for each lead time from 0 to 11 months.

\section{b. MOSIM Missouri River main-stem system model}

COE operates a series of six reservoirs along the main stem of the Missouri River. The operation of the reservoirs is governed by a master water control manual (COE 1979), which has been under review for several years to adapt the management of the main-stem system for ecological and other concerns (National Research Council 2002b; COE 2001). As part of the review, extensive studies by the COE have been made on the operation of the system, using a system simulation model at a monthly time step (COE 1994a). In addition to COE efforts, other researchers have developed Missouri River main-stem reservoir operation models (Hotchkiss et al. 2000; Jorgensen 1996; Lund and Ferreira 1996) though none were suitable for the goals of this study. Our need was to use a monthly time step, incorporate forecast information in operating decisions, and to produce hydropower benefits. We constructed a system model, MOSIM, using the Extend simulation software (Imagine That, Inc. 2001). MOSIM uses the physical reservoir data and minimum releases for hydropower and environmental constraints from the long-term study model described by the COE (1994a), which are shown 
TABLE 3. Dam release constraints and key elevations for the COE main-stem Missouri River project used in the MOSIM model.

\begin{tabular}{|c|c|c|c|c|c|c|}
\hline & $\begin{array}{l}\text { Fort Peck Dam; } \\
\text { Fort Peck Lake }\end{array}$ & $\begin{array}{l}\text { Garrison Dam; } \\
\text { Lake Sakakawea }\end{array}$ & $\begin{array}{l}\text { Oahe Dam; } \\
\text { Lake Oahe }\end{array}$ & $\begin{array}{c}\text { Big Bend } \\
\text { Dam; } \\
\text { Lake Sharpe }\end{array}$ & $\begin{array}{l}\text { Fort Randall } \\
\text { Dam; } \\
\text { Lake Francis } \\
\text { Case }\end{array}$ & $\begin{array}{c}\text { Gavins Point } \\
\text { Dam; } \\
\text { Lewis and } \\
\text { Clarke Lake }\end{array}$ \\
\hline & \multicolumn{6}{|c|}{ Release $\left(\mathrm{m}^{3} \mathrm{~s}^{-1}\right)$} \\
\hline Max release $^{a}$ & 708 & 1700 & 1925 & 2265 & 2265 & 2265 \\
\hline Max winter release ${ }^{b}$ & 425 & 708 & 708 & 708 & 708 & 708 \\
\hline Max hydropower & 453 & 1189 & 1670 & 3115 & 1303 & 991 \\
\hline Min hydropower ${ }^{\mathrm{c}}$ & 85 & 227 & 28 & 0 & 28 & 142 \\
\hline Min tern and plover ${ }^{d}$ & 241 & 566 & 0 & 0 & 793 & 821 \\
\hline \multirow[t]{2}{*}{ Min spawning, irrigation, and water supply ${ }^{\mathrm{d}}$} & 85 & 453 & 170 & 0 & 142 & 170 \\
\hline & \multicolumn{6}{|c|}{ Elevation (m) } \\
\hline Max flood control & 686.0 & 565.2 & 493.9 & 433.8 & 419.2 & 368.9 \\
\hline Max multiple use & 684.8 & 564.0 & 493.0 & 433.5 & 416.2 & 368.3 \\
\hline Max carryover & 681.1 & 560.2 & 490.1 & 432.9 & 411.6 & 367.2 \\
\hline Max permanent pool & 658.5 & 541.2 & 469.5 & 431.4 & 402.4 & 367.1 \\
\hline \multirow[t]{2}{*}{ Avg tailwater } & 620.1 & 511.0 & 434.5 & 412.5 & 376.5 & 354.0 \\
\hline & \multicolumn{6}{|c|}{ Volume at given elevation $\left(10^{6} \mathrm{~m}^{3}\right)$} \\
\hline Max elev flood control & 23050 & 29380 & 28540 & 2290 & 6680 & 580 \\
\hline Max elev multiple use & 21850 & 27550 & 27180 & 2220 & 5470 & 510 \\
\hline Max elev carryover & 18500 & 22340 & 23230 & 2070 & 3850 & 400 \\
\hline Max elev permanent pool & $665190 \mathrm{G}$ & 6140 & 6630 & 1740 & 1870 & 380 \\
\hline
\end{tabular}

a Values of 2265 indicate no defined maximum in the COE (1994) report.

${ }^{\mathrm{b}}$ Max flows are reduced in winter (DJF) due to channel ice formation.

${ }^{\mathrm{c}}$ Min hydropower is the sustained flow set to meet the Mid-Continent Area Power Pool (MAPP) requirements in the COE Long-Range Study (LRS) model.

${ }^{d}$ Min flows [from both COE (1994) and input files for the COE LRS model] applied May-Aug.

${ }^{\mathrm{e}}$ As the base of the multiple use zone, this is the target volume for 1 Mar in COE (1994).

in Table 3. We include the simplification used by Jorgensen (1996) and COE (1991) that combines local inflow to Big Bend and Fort Randall reservoirs. The small contributing area between Big Bend Dam and Oahe Dam justifies this assumption.

The three upstream reservoirs contain about $90 \%$ of the total system storage, and therefore provide the majority of the capacity to operate the system by draining during the fall and winter and refilling during spring. Therefore, in our system model the downstream three reservoirs are operated in a run-of-river mode, where for each month the inflow is equal to the outflow. The model determines the release from each reservoir at each

TABLE 4. Total system storage category definitions and navigation flow targets, adapted from COE (1994a) and Jorgensen (1996).

\begin{tabular}{lccc}
\hline \hline & High & Medium & Low \\
\hline & System storage definition $\left(10^{6} \mathrm{~m}^{3}\right)$ \\
Dec-Feb & 77710 & 71540 & 67840 \\
Mar-Apr & 67230 & 56740 & 49340 \\
May & 69080 & 59210 & 49340 \\
Jun-Nov & 72780 & 62290 & 49340
\end{tabular}

Service level flow (release target at Gavins Point)* $\left(\mathrm{m}^{3} \mathrm{~s}^{-1}\right)$ $\begin{array}{llll}\text { Dec-Feb } & 708 & 425 & 255\end{array}$

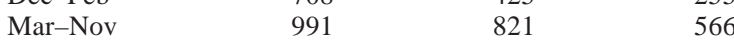

* Releases are based on the total system storage, as defined for the three categories of high, medium, and low. For system storages between the threshold values, flow targets are interpolated. time step in a two-step process. The first step consists of meeting the minimum and maximum flow release requirements in Table 3, and the release needed to evacuate reservoir storage in the winter to prepare for spring inflow volumes, which is set to match the current operational goal of draining each reservoir to the base of the multiple use zone by 1 March (COE 1994a). Shortfalls in meeting environmental targets up to $10 \%$ are permitted to occur in the model when the total system storage is below the top of the carryover storage zone. This process is run from the most upstream dam (Fort Peck) downstream to Gavins Point. The second step involves checking the release at Gavins Point to see if the navigation target, which is a function of date and system storage (COE 1994a) as shown in Table 4, has been met by the releases determined in the first step. If a supplemental release is needed to meet the navigation flow at Gavins Point, this is allocated to the upper three reservoirs with the supplemental release drawn from each reservoir in proportion to its current volume. This helps to balance the levels of the three upstream reservoirs, which is an operational goal with the Missouri River main-stem system, described by COE (1994a). These supplemental releases are passed through the system to determine the final releases at each dam.

Figure 3 compares the historic systemwide monthly storage for 1968-97 with that simulated by the system model, MOSIM, using the historic monthly reservoir inflows. The mean monthly bias is $-557 \times 10^{6} \mathrm{~m}^{3}$, or 


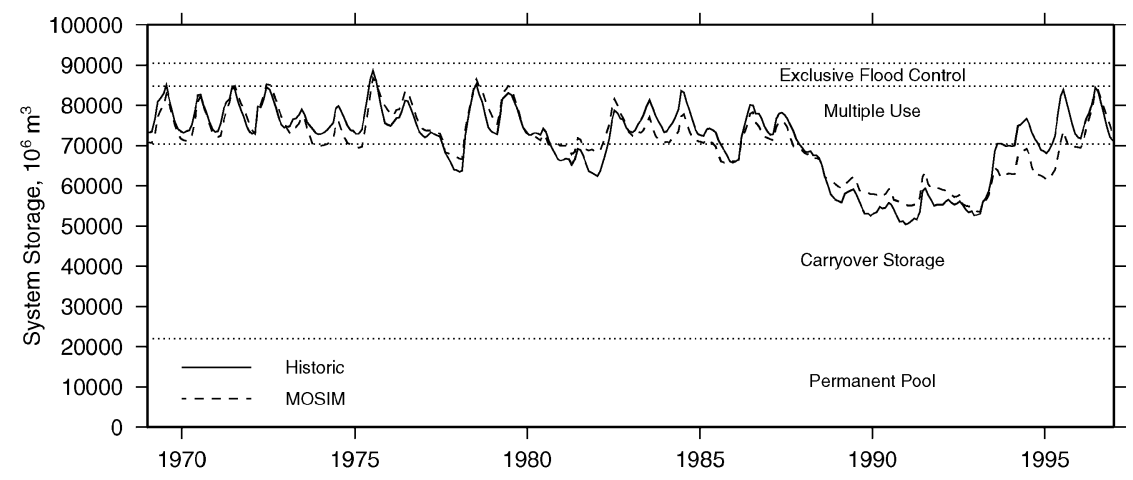

FIG. 3. Monthly simulated and historic Missouri River main-stem system volumes: 1968-97.

$0.8 \%$ of the average historic system storage. The rootmean-square error of monthly storage volumes is 3.458 $\times 10^{9} \mathrm{~m}^{3}$, or $4.8 \%$, and the Pearson correlation coefficient of the historic and simulated monthly volumes is 0.92 , which reflects the good correspondence between the model and historic system simulation seen in Fig. 3.

MOSIM includes a computation of system energy capacity and generation for each dam. System energy capacity is a function of reservoir elevation [tables relating elevation to capacity used in MOSIM are those used by COE (1994a)], and is an indication of the ability of the system to generate peak power. Maintaining high reservoir levels increases the potential peak power generation capability, thus increasing the system capacity benefits. Energy generation is a function of discharge and water surface elevation at each reservoir, and is the energy produced when water is released from a reservoir through its turbines. Historic and simulated (using MOSIM with observed historic reservoir inflows) energy generation (in GW h) for each month for 196897 are shown in Fig. 4. The annual average historic energy generation is $10187 \mathrm{GW} \mathrm{h}$, and the simulated value is nearly identical at 10 158. Although Fig. 4a shows that MOSIM overpredicts the peak generation during the low system storage period during the late 1980s and early 1990s (when MOSIM has higher reservoir elevations than historic values), Fig. 4b shows that the model captures the seasonal average cycle accurately.

\section{c. Forecasted inflows representing predictability levels}

To contrast the effects of different levels of predictability on the system operation, it was necessary to develop forecasted inflow sequences that reflect each predetermined level of predictability. This was accomplished by stochastically adding error to observed system inflow sequences, with larger errors reflecting lower levels of predictability, and perfect predictability resulting in forecasted flows equal to observed. The method used, based on Lettenmaier (1984), is outlined in the appendix. In order to extend this analysis further into the past, we used as a surrogate for the historic record the 100-yr reconstructed historic reservoir inflows developed by COE (1994a), which remove the effects of upstream water management and set a constant depletion level at the relatively low level present in 1949.

For each month of the historic record for each contributing area, 500 synthetic forecasts were made for each of the following 12 months, reflecting the $C_{p}$ values for the current month. From this sequence, the 90th percentile flow for each month was determined. (Since the focus was on high-flow conditions, no adjustment was necessary for the possibility of negative flows as they do not occur at the 90th percentile level.) These 90th percentile flows represent the assumed level of risk $(10 \%)$ for this study [and the highest runoff conditions, or "upper decile," used in planning reservoir releases

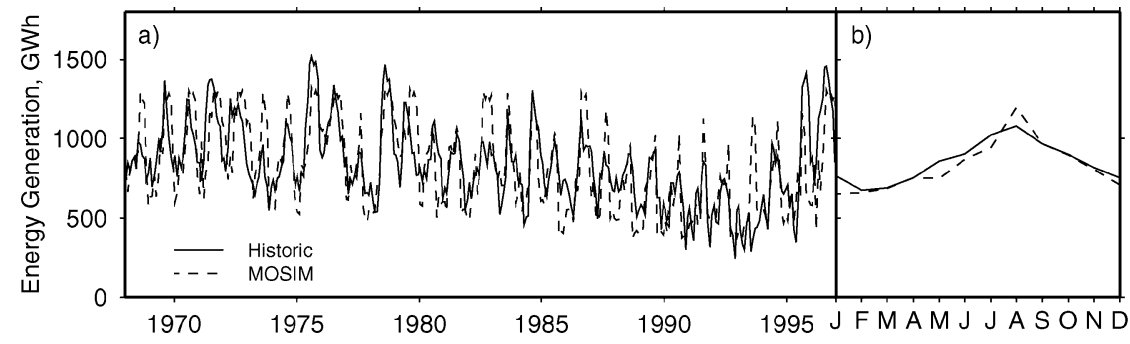

FIG. 4. Monthly energy generation of Missouri River main-stem dams, historic and simulated.

(a) Time series of monthly values; (b) average annual cycle for the 50-yr period, 1968-97. 


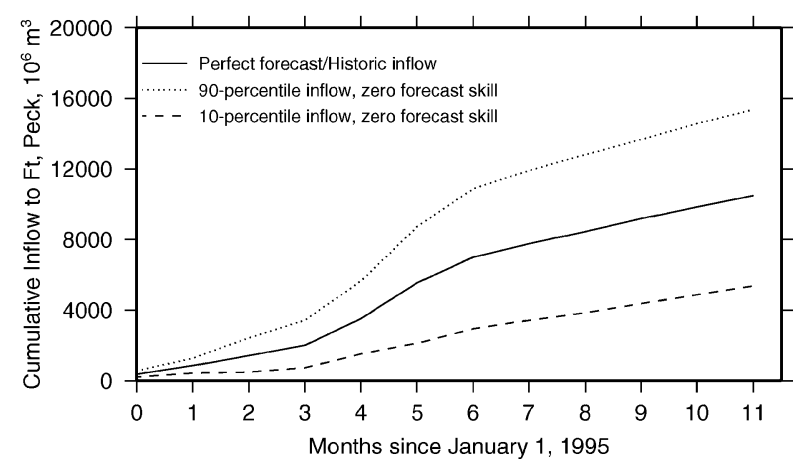

FIG. 5. Accumulated inflow to Fort Peck Dam for a 12-month forecast period under conditions of perfect and zero forecast skill.

in COE (1979)], where operational decisions are based on these anticipated flow volumes for the following 12 months. An example of the generation of forecasted flow sequences is shown in Fig. 5 for the case of no predictability (all $C_{p}$ values set to 0 ). This shows the widening band of uncertainty as the forecast lead time increases.

\section{d. The value of added predictability}

To compare the benefits associated with different levels of predictability quantitatively, it is convenient to compute system economic benefits under different alternatives. The current COE system operation produces many benefits, including flood control, navigation, hydropower, water supply, and recreation. In addition, the system is operated to provide environmental mitigation benefits, including habitat protection for the least tern and piping plover populations that nest along the river. Among these benefits, hydropower dominates the total (COE 1994a). For the MOSIM model developed for this study, the remaining purposes for the reservoir system were imposed as constraints, while differences in hydropower generation under different alternatives provided the metric for the value of the predictability. Hydropower benefits were calculated for system capacity and energy production. COE (1994a) estimated that the capacity has historically generated roughly two-thirds of the total hydropower benefits. The economic benefits of both capacity and energy vary through the year. A set of monthly capacity and energy benefits were derived based on COE (1994b), which are shown in Table 5.

The annual operation in MOSIM was based on COE (1994a), which uses a target of draining all reservoirs (in the case of MOSIM, the three upper reservoirs only, as the lower three are "run of river") to the target el- evation corresponding to the base of the annual flood control zone (also referred to as the flood control and multiple use zone) by 1 March. In order to permit the use of long-lead forecast information, this rule was altered to use two forecast volumes, both derived at the 90th percentile level as above. First, rather than fix the 1 March level to the base of the multiple use zone, the level was set to allow storage of the forecasted volume of spring and summer inflow (March-July) less than the maximum amount that could be released through the turbines, in order to minimize spill. Second, the forecasted inflow volume from the current month through 1 March was compared against the maximum volume that could be released through the turbines by 1 March. This allowed a decision each month as to whether the evacuation needs to begin or not, and retained the reservoir at as high a level as possible until lowering of levels to meet the 1 March target must begin. Table 5 shows how maintaining higher water surface elevations, especially in DJF and JJA, can result in increased system benefits due to greater economic value of energy production and capacity. Additional predictability, and hence reduced uncertainty in anticipated flow volumes, allows the maintenance of higher reservoir levels, which translate into greater hydropower benefits, and provides a quantitative estimate of benefits due to additional predictive skill.

With the addition of this capability of the system to respond to different levels of predictability, the system operation changes, as shown in Fig. 6 for the cases of perfect and zero predictability. It is interesting to note that even the zero predictability case has considerably less drawdown of the system during the dry period of the late 1980s to early 1990s. This illustrates that because the synthetic forecast technique adds noise to the historic inflows, even a zero predictability scenario effectively incorporates some knowledge of future inflows, and does not represent a true "zero skill" forecast, which would assume climatological inflows. This also shows how a change in operation of a system may produce additional benefits that can exceed those due to increases in predictability.

\section{Results and discussion}

\section{a. Current system configuration}

As a bounding case, the annual systemwide hydropower benefits under a perfect forecast scenario (complete knowledge of future flows) are compared to those resulting from no predictability. The average annual hydropower benefits for the no predictability scenario were

TABLE 5. Energy and capacity values used in this study.

\begin{tabular}{|c|c|c|c|c|c|c|c|c|c|c|c|c|}
\hline & Jan & $\mathrm{Feb}$ & Mar & Apr & May & Jun & Jul & Aug & Sep & Oct & Nov & Dec \\
\hline Energy $\left[10^{-3} \$(\mathrm{~kW} \mathrm{~h})^{-1}\right]$ & 21.00 & 21.00 & 19.00 & 19.00 & 19.00 & 27.00 & 27.00 & 27.00 & 19.80 & 19.80 & 19.80 & 21.00 \\
\hline Capacity $\left(\$ \mathrm{~kW}^{-1} \mathrm{month}^{-1}\right)$ & 13.26 & 9.62 & 5.33 & 0 & 4.01 & 18.44 & 30.10 & 26.73 & 12.99 & 1.36 & 7.32 & 12.99 \\
\hline
\end{tabular}




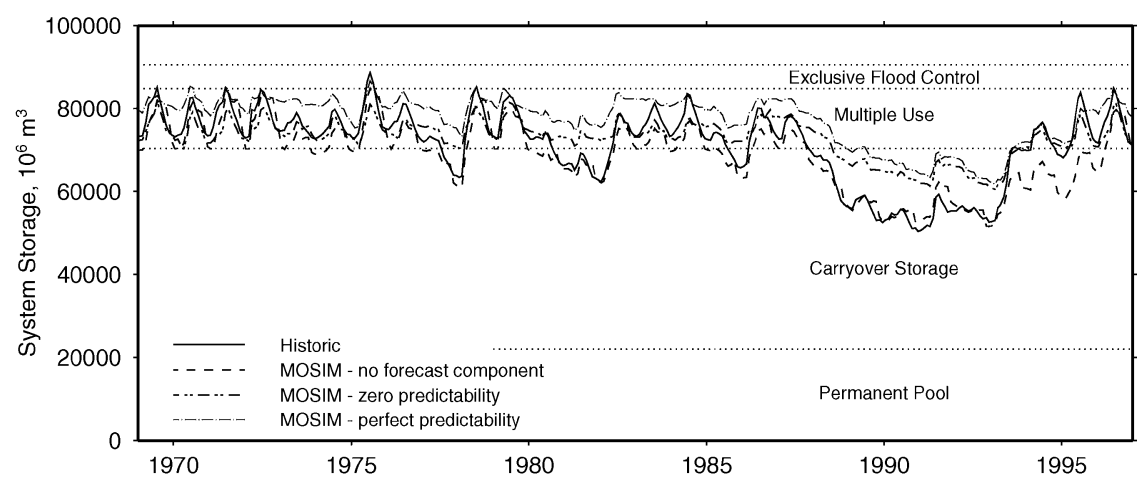

FIG. 6. Monthly historic and simulated main-stem system storage, as in Fig. 3, but including the system operation under the flexible rule curve adopted in this study to adapt operations to different levels of predictability. MOSIM-no-forecast component corresponds to the MOSIM model plotted in Fig. 3.

$\$ 530$ million, while the perfect forecast scenario produced $\$ 540$ million, representing an increase of $1.8 \%$. (For comparison, MOSIM without a forecast component, which more closely follows the historic system operation illustrated in Fig. 6, produces \$510 million in hydropower benefits.) This suggests a relative maximum potential benefit in the Missouri River basin, due to hydropower alone, with improved predictability that amounts to several million dollars but is small on the scale of the benefits already produced by the project.

This result is reasonable, given the scale of the existing project, where the total system storage (of the COE main-stem projects) is 3 times the annual inflow to the reservoirs. As illustrated in Fig. 5, the greatest volume of water affected by the forecast in a month (i.e., the maximum difference in slope between perfect and zero predictability), is approximately $900 \times 10^{6}$ $\mathrm{m}^{3}$. This volume of water can be interpreted as an

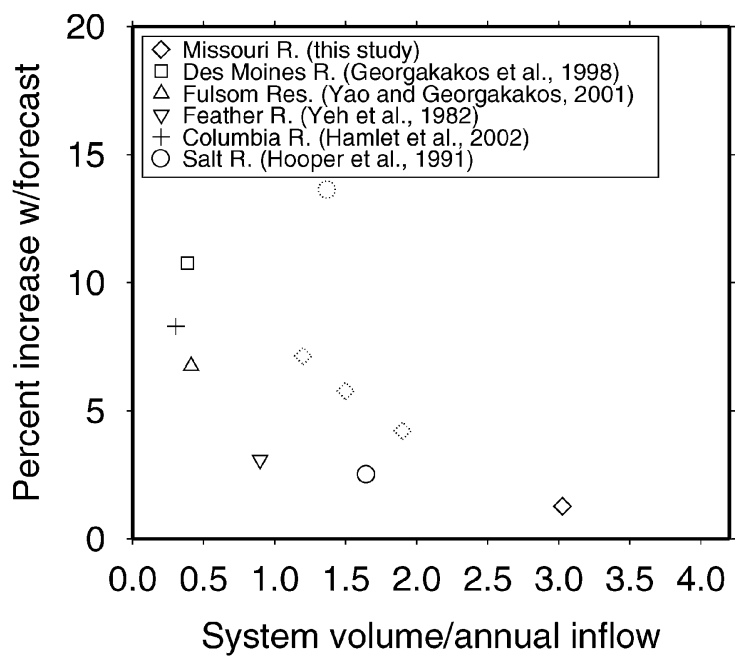

FIG. 7. Ratio of system volume to annual system inflow vs the percent difference between perfect and no-forecast skill for past studies and the current study. Dotted symbols indicate sensitivity studies for reduced volume systems (see discussion in text). amount that can be stored under perfect forecast knowledge, while with zero predictability it would have to be released to leave room to store anticipated inflow (that would not ultimately occur). However, the extremely large size of the reservoirs relative to the inflows results in this volume representing an elevation difference, at Fort Peck dam, of $1.0 \mathrm{~m}$, or $1.5 \%$ of the total head available for hydropower generation at Fort Peck. Similarly, the large reservoirs impounded by the Garrison and Oahe dams relative to their inflows dampen the sensitivity to inflow forecasts, resulting in the relatively small range of benefits under perfect and no skill forecasts.

To put this information in the context of past studies, we compiled the results from five previous studies that compared hydropower generation benefits under perfect forecast (or under optimal operation) and with zero predictability (or with little accounting for forecast knowledge). For each of these past studies, Fig. 7 shows the ratio of system volume to annual inflow versus the percent difference in hydropower benefits with the best forecast as compared to least or no predictability. Although the value of predictability is a function of many factors such as the variability of inflows and demands, and the studies employ a variety of assumptions, Fig. 7 shows that the ratio of system volume to average inflow does provide some apparent limitation to the potential of a system to benefit from forecast information. As an extreme case (large storage relative to mean flow), the Missouri River main stem falls within the trajectory seen from past studies, showing that 12 -month forecasts in this study have a limited effect on this system, designed for multiple year storage.

Given this inverse relationship between reservoir system storage capacity and the hydropower benefits of long-lead forecast information, we studied the benefits of added predictability on a hypothetical reduced-volume system in the Missouri River basin. Hooper et al. (1991) included this type of sensitivity study of the effect of reducing system storage volume on the benefits 
TABLE 6. Data related to the sensitivity study with resizing of the main-stem Missouri River system reservoirs.

\begin{tabular}{cccc}
\hline \hline $\begin{array}{c}\text { Total } \\
\text { system } \\
\text { volume } \\
\left(10^{6} \mathrm{~m}^{3}\right)\end{array}$ & $\begin{array}{c}\text { System (vol/ } \\
\text { annual flow) } \\
\text { at Gavins Point }\end{array}$ & $\begin{array}{c}\text { Avg elev range in } \\
\text { multiple use } \\
\text { zone }(\mathrm{m})\end{array}$ & $\begin{array}{c}\text { Increase in benefits } \\
\text { with perfect } \\
\text { forecast }(\%)\end{array}$ \\
\hline 90520 & 3.0 & 3.0 & 1.8 \\
58240 & 1.9 & 5.4 & 4.2 \\
45420 & 1.5 & 7.3 & 5.8 \\
36450 & 1.2 & 15.2 & 7.1 \\
\hline
\end{tabular}

of forecast information. To simulate the effects of a volume reduction due to system modification, Hooper et al. reduced their simulated system storage capacity by $17 \%$, and the resulting difference between a perfect and zero forecast increased markedly to $13.6 \%$ (the reduced capacity Salt River system is shown in Fig. 7 as dotted symbols). The Salt River system Hooper et al. analyzed may be more sensitive to changes in system storage than the Missouri River main-stem system, because the Salt River system relies on costly groundwater pumping to achieve water supply requirements not met by surface runoff, and the pumping cost is included in their analysis. However, it does show that a reduction in total system capacity may result in greater forecast value. In the present study, a similar sensitivity study was performed for two purposes: 1) to identify a system capacity at which the value of forecast information provides a greater marginal increase in benefits; and 2) to examine the value of the climate, snow, and soil moisture information within the bounds of perfect and zero predictability.

\section{b. Modified system configuration}

Although the current storage capacity of the Missouri River main-stem reservoirs is too large to show a substantial difference in hydropower benefits between different levels of predictability, for reasons discussed above, a smaller system in the same geographical setting is expected to show greater sensitivity. To investigate this, the MOSIM model was altered by reducing the total capacities of the carryover storage and permanent pool zones of the three upstream reservoirs, resulting in a hypothetical system with smaller reservoir storage capacities that is more sensitive to changes in forecasted inflows. The three reduced Missouri system configurations are summarized in Table 6 . The smaller system sizes result in a greater range of elevations for the multiple use zone (which retained its original size for all configurations), and the value of forecast information relative to no forecast knowledge likewise increases. The smallest system, with a volume-to-flow ratio of 1.2 , showed a difference of $7.1 \%$ in hydropower benefits between the perfect and zero predictability alternatives, representing a difference of $\$ 25.7$ million in annual average hydropower benefits.
TABLE 7. Total system hydropower benefits for reduced-volume Missouri River main-stem dams under different levels of predictive skill.

\begin{tabular}{lc}
\hline \hline \multicolumn{1}{c}{ Scenario/forecast knowledge } & $\begin{array}{c}\text { Average annual } \\
\text { hydropower benefits } \\
\text { (millions of dollars) }\end{array}$ \\
\hline Zero forecast skill & $\$ 359.8$ \\
Climate state & $\$ 363.2$ \\
Climate state and snow water content & $\$ 364.5$ \\
Climate, snow, and soil moisture & $\$ 366.6$ \\
Lag flow forecast & $\$ 363.5$ \\
Perfect forecast skill & $\$ 385.5$ \\
\hline
\end{tabular}

For this study, this reduced main-stem system was used in the analysis of the value of forecast information added by knowledge of the climate state and the initial state of snow water and soil moisture, as developed by Maurer and Lettenmaier (2003). The three cases of incremental knowledge of climate and land surface state identified in section 3 a were applied to this reduced main stem system. The total hydropower benefits of the project using these three cases, bounded by the hydropower benefits for perfect and zero predictability scenarios, are summarized in Table 7. Figure 8 shows the system reliability in meeting the minimum environmental flow releases for the least tern and piping plover habitat at the Fort Peck and Garrison dams. Figure 8 shows that the reliability of meeting these release targets is generally equal or better under greater predictability and higher benefit alternatives. In addition, the maximum winter releases are met $100 \%$ of the time at these points, as are the navigation release targets at Gavins Point. This illustrates that the increase in benefits between these alternatives is not due to a reduction in reliability in meeting some other system benefit.

Table 7 shows that for this reduced configuration of the Missouri River main-stem reservoir system, the total potential annual hydropower gain above zero predictability accounting for the climate state, with perfect knowledge of the snow water content and soil moisture,

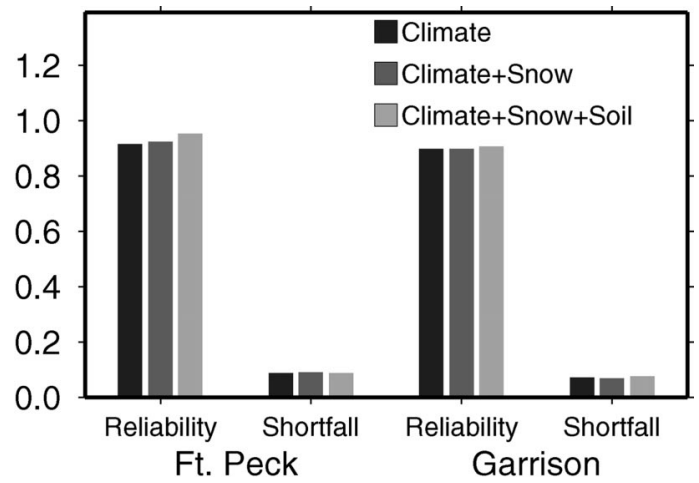

FIG. 8. Reliability of system for meeting environmental release targets at the Fort Peck and Garrison dams, measured as the fraction of time that the releases are met, and the averge magnitude of each shortfall expressed as a fraction of the target release. 
amounts to $\$ 6.8$ million annually, which is $26 \%$ of the total difference between zero and perfect predictability. Using currently available knowledge of the climate signal, with no knowledge of snow or soil moisture states, provides $\$ 3.4$ million in benefits above the no-predictability case. The incremental benefit of perfectly knowing snow state, in excess of the benefit resulting from knowledge of climate state, is $\$ 1.3$ million. Although soil moisture shows high predictability at lead times less than three months and has its highest correlations for predictability of winter runoff, when runoff is lowest, the incremental benefit (above that already achieved with snow and climate knowledge) due to perfect knowledge of soil moisture state is \$2.1 million. As noted in section $3 \mathrm{a}$, the predictability of summer runoff attributable to knowledge of snow water is high at Fort Peck, but lower at the more downstream projects; hence, snow has an overall system impact less than that due to soil moisture.

Using the SOI and AO climate indices, which are published monthly (and are therefore available at forecast time), the hydropower benefits obtained from 12month forecasts, in excess of those for the no-predictability scenario, are approximately equal to that which can be obtained using only past inflow observations (the "lag flow" forecast indicated in Table 7). When a perfect knowledge of the basin snow and soil moisture state at the time the forecast is made is added to knowledge of the climate indices, the total increase in hydropower benefits (above a no-predictability scenario) double.

It should be emphasized that these results apply to the entire (reduced volume) main-stem system. Other projects in the basin would have different sources and levels of predictability, and the dominance of these sources in producing hydropower benefits would be different. Furthermore, as noted by Yao and Georgakakos (2001), the response of a water resources system to forecast information is highly dependent on the reservoir operating rules imposed. Hence, the conclusions from the present study, with system operations based on those used by the COE long-term simulation model, would be expected to change under different operating rules.

The results in Table 7 are also dependent on the order in which the tiers of variables are introduced. As mentioned above, the best known variables are introduced first, hence, any predictability associated with correlated variables is assigned to the better known variables. The implication of this on the results in Table 7 is that, for example, if it were assumed that soil moisture could be characterized using a hydrologic model to better accuracy than snow water content is observed, soil moisture would be introduced before snow in the development of the $C_{p}$ values in Table 2 . This would attribute a greater portion of the total variance explained to soil moisture (because soil moisture and snow water are correlated), and therefore a greater proportion of incremental benefits shown in Table 7 would be assigned to soil moisture.

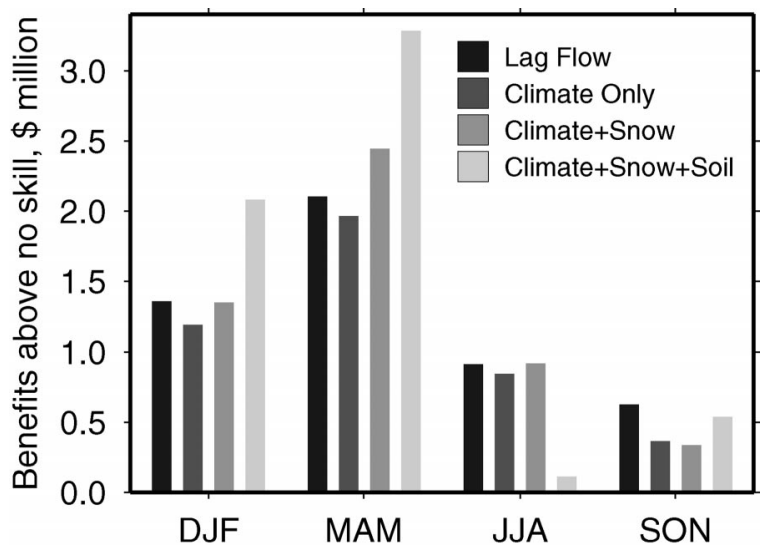

FIG. 9. Average annual hydropower benefits above a no-forecast skill scenario with the specified level of predictability in the current season, and no skill in other seasons. Seasons are as defined in Table 2.

\section{c. Seasonal distribution of predictability}

The seasonal distribution of the value of this predictability was investigated by generating forecasts using different levels of predictability (either a lag flow forecast, or some combination of knowledge of climate state, snow water content, and soil moisture) in one season, and no predictability in the remaining seasons. The benefits determined for hydropower used the reduced volume system configuration. The resulting benefits are shown in Fig. 9, where, for example, DJF indicates the predictability level for forecasts made in winter was set using the appropriate values for the level of knowledge indicated, and zero predictive skill was assigned to the other three seasons. The ordinate values indicate the average annual system hydropower benefits above those obtained with no predictability.

Figure 9 shows several interesting features on the seasonal scale. First, the benefits obtained from incorporating the known climate indices (labeled "climate only" in Fig. 9) in the prediction scheme are very close to the benefits obtained using correlation relationships with historic observed flows (lag flow). The incremental benefits (beyond those already obtained using climate indices) obtained with perfect knowledge of snow state throughout the basin has its major impact in spring, when the high spring and summer flow volumes are highly correlated with snowpack and soil moisture. Even with the constraint of the system operation in this study, where in MAM the next reservoir target is the following 1 March, the volume of water affected by the initial land surface conditions is large enough, and has sufficient persistence, where there is considerable value to the predictability.

In general, the value of predictability is greatest in the spring, when interannual variability is greatest (Fig. $2 c)$. The winter and spring are when the incremental benefits due to soil moisture knowledge, above those already obtained from knowledge of climate and snow, are greatest. This illustrates the potential value of soil 
moisture knowledge in determining spring and summer inflows. Knowledge of soil moisture also provides incremental benefits during fall (though of a lower value due to lower flows during this part of the year), since the low winter inflows are dominated by soil moisturedriven base flow.

Using this technique to examine the seasonal value of predictability has some counterintuitive results. One illustration of this is seen for summer in Fig. 9, where increasing information about the land surface moisture state in summer (with no skill in all other seasons) results in a decrease in average annual benefits. This is explained by the use of the flexible rule curve to set the 1 March system evacuation target, and the nonlinearity of monthly benefits. For example, knowledge of soil moisture in summer provides some predictability of upcoming fall and winter inflows to the system. With the added predictability in summer, anticipated inflows in fall and winter might be low and releases limited accordingly. However, when the system returns to no skill forecasts the following season, higher anticipated inflows will result, and reservoir releases will increase for the fall. This would effectively shift releases from summer to fall with added predictability in only the summer season. This timing shift in releases from summer to fall would result in lower hydropower benefits, as shown by the values in Table 5. This further illustrates the complex interactions between not only the time-varying predictability and the operating rules of the system, but also the effect of the time value of energy, and how these factors all play a role in the ultimate value of hydrologic predictability in any particular setting.

\section{Conclusions}

The value of long-lead streamflow prediction skill added by knowledge of climate teleconnection information and land surface moisture state in the Missouri River basin on the main-stem reservoir system was evaluated. The value was based on the hydropower generated by the main-stem dams for a simulated period of 1898-1996 using a monthly simulation model developed for this study. Simulated forecasted flows were generated to represent the levels of predictability determined in a previous study.

The configuration of the Missouri River main-stem reservoirs, which have a total storage capacity 3 times the average annual discharge at the downstream end of the system, shows little sensitivity to streamflow prediction skill at long lead times (months to a year)—only a $1.8 \%$ difference in hydropower benefits between a zero and perfect skill forecast. Modifications to the system operation to allow ingestion of forecasted inflows had a greater overall effect on hydropower benefits than the added prediction skill.

To simulate the effects of predictability on a smaller system, a hypothetical Missouri River main-stem system was developed with reduced system storage. This re- duced system showed a larger difference between the zero and perfect predictability case of $7.1 \%$, and allowed the investigation of the levels of predictability due to climate and land surface state knowledge to be investigated. With the reduced system, incorporating both a knowledge of the climate state as well as perfect knowledge of snow and soil moisture states in the forecast resulted in an increase of $1.9 \%$ in system hydropower benefits, representing $\$ 6.8$ million annually. Of this $\$ 6.8$ million, use of currently available climate indices provides the largest portion at $\$ 3.4$ million, which is approximately the same as the value of predictability provided by historically observed inflows. Of the additional benefits above that already provided due to climate knowledge, soil moisture adds the greatest value, at \$2.1 million. This provides an important context for operational implementation of hydrologic predictability, where for large water resources systems the benefits of added predictability may amount to modest sums, but represent a small percentage of additional benefits.

A seasonal analysis indicates that, for the reduced system, including climate knowledge alone provides a level of benefits comparable to that obtainable using historic system inflow observations. Benefits above those obtainable using historic inflows can be obtained with the addition of knowledge of snow water content and soil moisture throughout the basin. Knowledge of soil moisture provides the bulk of these increased benefits, and has its greatest impact when knowledge is provided of soil moisture state in the winter and spring.

Acknowledgments. This research was supported by the Joint Institute for the Study of the Atmosphere and Ocean (JISAO) under NOAA Cooperative Agreement NA17RJ11232 and by a NASA Earth System Science Fellowship to the first author. The development of the MOSIM model would not have been possible without the generous assistance of Michael Swenson of the U.S. Army Corps of Engineers, Reservoir Control Center, Missouri River Region. Alan Hamlet of the University of Washington provided valuable guidance with the logic used in the system model. This manuscript benefited from the careful review and valuable comments of two anonymous reviewers.

\section{APPENDIX}

\section{Development of Forecast Reservoir Inflows}

Lettenmaier (1984) defined an index of forecast skill, the coefficient of prediction:

$$
C_{p}=1-\frac{E\left(\tilde{X}_{t}-X_{t}\right)^{2}}{\sigma_{t}^{2}},
$$

where $\tilde{X}_{t}$ is the forecasted flow at time $t, X_{t}$ denotes the recorded flow, and $\sigma_{t}$ is the standard deviation of the recorded flows in period $t$. For the predictabilities determined by Maurer and Lettenmaier (2003) using mul- 
tiple linear regression techniques, $C_{p}$ is numerically equal to the square of the correlation coefficient, that is, the fraction of the runoff variance explained by the predictors.

For a given level of forecast skill, forecasted flows are developed from the "recorded" flows as follows. As represented by Lettenmaier (1984), forecast flows are equal to recorded flows plus an additive error component:

$$
\tilde{X}_{t}=X_{t}+\varepsilon_{t}
$$

where $\varepsilon_{t}$ is an error term that grows as the forecasts contain less skill. The forecast error is a function of the forecast accuracy, with zero error associated with a perfect forecast and the maximum error associated with noforecast skill. In order to generate errors for different scenarios of forecast skill, the following methodology was used.

The error term, $\varepsilon_{t}$, is normally distributed with a mean of zero and a variance computed by

$$
\sigma_{\varepsilon}^{2}=\left(1-C_{p}\right) \sigma_{t}^{2},
$$

where $\sigma_{t}$ is the standard deviation of the recorded flows in period $t$; in this case $t$ represents months, so $\sigma_{t}$ is the standard deviation of the set of flows for month $t$. In Lettenmaier (1984) the $\varepsilon_{t}$ is assumed to have a lag-1 (using daily data) Markov correlation structure. The effective lag-1 correlation coefficient, $\rho$, of the recorded flow is derived such that the established value of $C_{p}$ is reproduced. The lag-1 forecast error correlation, $\rho_{\varepsilon}$ is estimated, which is a function $\rho$ and the length of the forecast and observation periods. As illustrated in the implementation of this technique by Datta and Burges (1984), as well as in the example in Lettenmaier (1984), even very large values of $C_{p}$ and $\rho$ produce relative low correlation values of $\rho_{\varepsilon}$. In this implementation, $\rho_{\varepsilon}$ was estimated at below 0.1 for the range of $C_{p}$ values reported by Maurer and Lettenmaier (2003), and would therefore have a negligible effect on the estimated forecast values. Hence, the forecast errors were assumed uncorrelated for this study. With these assumptions, this method reduces to that used by Yeh et al. (1982) for stochastic flow generation.

\section{REFERENCES}

Baldwin, C. K., 2001: Seasonal streamflow forecasting using climate information. Proc. 69th Western Snow Conf., Sun Valley, ID, Western Snow Conference, 95-98.

Carroll, S. S., T. R. Carroll, and R. W. Poston, 1999: Spatial modeling and prediction of snow water equivalent using ground-based, airborne, and satellite snow data. J. Geophys. Res., 104, $19623-$ 19629 .

Castruccio, P. A., H. L. Loats, D. Lloyd, and P. A. B. Newman, 1980: Cost/benefit analysis in the operational application of satellite snowcover operations. Operational Applications of Satellite Snowcover Operations, A. Rango and R. Peterson, Eds., NASA Conference Publication 2116, NASA Scientific and Technical Information Office, 239-254.

Cayan, D. R., K. T. Redmond, and L. G. Riddle, 1999: ENSO and hydrologic extremes in the western United States. J. Climate, 12, 2881-2893.

COE 1979: Missouri River main stem reservoir system reservoir regulation manual. Vol. 1, Master manual, Missouri River Division, Omaha, NE.

1991: Missouri River system analysis model—Phase I. Hydrologic Engineering Center, Davis, CA, 34 pp. +5 appendixes. 1994a: Missouri River master water control manual review and update. Vol. 2. Reservoir regulation studies, long range study model, Missouri River Division.

—_, 1994b: Missouri River master water control manual review and update. Vol. 6D. Economic studies, Missouri River Division.

_ 1998: Missouri River main stem reservoirs: System description and operation. Northwestern Division, Missouri River Region, Reservoir Control Center, 28 pp.

__ 1999: Missouri River main stem reservoirs hydrologic statistics. Missouri River Region, Reservoir Control Center RCC Tech. Rep. F-99, 45 pp.

_ 2001: Missouri River master water control manual review and update, revised draft environmental impact statement. Northwestern Division, Omaha, NE.

Datta, B., and S. J. Burges, 1984: Short-term, single, multi-purpose reservoir operation: Importance of loss functions and forecast errors. Water Resour. Res., 20, 1167-1176.

Dracup, J. A., and E. Kahya, 1994: The relationships between U.S. streamflow and La Niña events. Water Resour. Res., 30, 2133 2141.

Fennessy, M. J., and J. Shukla, 2000: Seasonal prediction over North America with a regional model nested in a global model. $J$. Climate, 13, 2605-2627.

Garen, D. C., 1998: ENSO indicators and long-range climate forecasts: Usage in seasonal streamflow volume forecasting in the western United States. Eos, Trans. Amer. Geophys. Union, 79, F325.

Georgakakos, K. P., A. P. Georgakakos, and N. E. Graham, 1998: Assessment of benefits of climate forecasts for reservoir management in the GCIP region. GEWEX News, 8, 5-7.

Goddard, L., S. J. Mason, S. E. Zebiak, C. F. Ropelewski, R. Basher, and M. A. Kane, 2001: Current approaches to seasonal-to-interannual climate predictions. Int. J. Climatol., 21, 1111-1152.

Hamlet, A. F., and D. P. Lettenmaier, 1999: Columbia River streamflow forecasting based on ENSO and PDO climate signals. ASCE J. Water Resour. Plan. Manage., 125, 333-341.

- D. Huppert, and D. P. Lettenmaier, 2002: Economic value of long-lead streamflow forecasts for Columbia River hydropower. ASCE J. Water Resour. Plann. Manage., 128, 91-101.

Hooper, E. R., A. P. Georgakakos, and D. P. Lettenmaier, 1991: Optimal stochastic operation of the Salt River Project, Arizona. ASCE J. Water Resour. Plann. Manage., 117, 566-587.

Hornberger, G. M., and Coauthors, 2001: A plan for a new science initiative on the global water cycle. U.S. Global Change Research Program, Washington, DC, $118 \mathrm{pp}$.

Hotchkiss, R. H., S. F. Jorgensen, M. C. Stone, and T. A. Fontaine, 2000: Regulated river modeling for climate change impact assessment: The Missouri River. J. Amer. Water Resour. Assoc., 36, 375-386.

$\mathrm{Hu}$, Q., and S. Feng, 2001: Variations of teleconnection of ENSO and interannual variation in summer rainfall in the central United States. J. Climate, 14, 2469-2480.

Imagine That, Inc., 2001: Extend Professional Simulation Tool Version 5. Imagine That, Inc.

Jorgensen, S. F., 1996: Hydrologic modeling of Missouri River reservoirs in a climate model. M.S. thesis, Civil Engineering Dept., University of Nebraska, Lincoln, Nebraska, 109 PP.

Kahya, E., and J. A. Dracup, 1993: U.S. streamflow patterns in relation to El Niño/Southern Oscillation. Water Resour. Res., 29, 2491-2503.

Lettenmaier, D. P., 1984: Synthetic streamflow forecast generation. ASCE J. Hydraul. Eng., 110, 277-289.

Lund, J. R., and I. Ferreira, 1996: Operating rule optimization for 
the Missouri River reservoir system. ASCE J. Water Resour. Plann. Manage., 122, 287-295.

Maurer, E. P., and D. P. Lettenmaier, 2003: Predictability of seasonal runoff in the Mississippi River basin. J. Geophys. Res., 108, 8607, doi:10.1029/2002JD002555.

, A. W. Wood, J. C. Adam, D. P. Lettenmaier, and B. Nijssen, 2002: A long-term hydrologically based dataset of land surface fluxes and states for the conterminous United States. J. Climate, 15, 3237-3251.

National Research Council, 2002a: Workshop on Predictability and Limits-to-Prediction in Hydrologic Systems. National Academy Press, 118 pp.

, 2002b: The Missouri River ecosystem: Exploring the prospects for recovery. National Academy Press, $188 \mathrm{pp}$.

Pauwels, V. R. N., R. Hoeben, N. E. C. Verhoest, and F. P. De Troch, 2001: The importance of spatial patterns of remotely sensed soil moisture in the improvement of discharge predictions for smallscale basins through data assimilation. J. Hydrol., 251, 88-102.
Rango, A., A. E. Walker, and B. E. Goodison, 2000: Snow and ice. Remote Sensing in Hydrology and Water Management, G. A. Schultz and E. T. Engman, Eds., Springer-Verlag, 239-262.

Reisner, M., 1986: Cadillac Desert. Viking Penguin, 514 pp.

__ , and S. Bates, 1990: Overtapped Oasis: Reform or Revolution for Western Water. Island Press, $196 \mathrm{pp}$.

Walker, J. P., and P. R. Houser, 2001: A methodology for initializing soil moisture in a global climate model: Assimilation of near surface soil moisture observations. J. Geophys Res., 106, 11 761-11 774.

Wood, A. W., E. P. Maurer, A. Kumar, and D. P. Lettenmaier, 2002: Long range experimental hydrologic forecasting for the eastern U.S. J. Geophys. Res., 107, 4429, doi:10.1029/2001JD000659.

Yao, H., and A. Georgakakos, 2001: Assessment of Folsom Lake response to historical and potential future climate scenarios. 2: Reservoir management. J. Hydrol., 249, 176-196.

Yeh, W. W.-G., L. Becker, and R. Zettlemoyer, 1982: Worth of inflow forecast for reservoir operation. J. Water Resour. Plann. Manage., 108, 257-269. 